\title{
Vigilance in Cattle: The Influence of Predation, Social Interactions, and Environmental Factors
}

\author{
Bryan M. Kluever, ${ }^{1}$ Stewart W. Breck, ${ }^{2}$ Larry D. Howery, ${ }^{3}$ Paul R. Krausman, ${ }^{4}$ and David L. Bergman ${ }^{5}$ \\ Authors are ${ }^{1}$ Wildlife Biologist, Hayden-Wing Associates, 2308 South 8th Street, Laramie, WY 82072, USA; ${ }^{2}$ Research Wildlife Biologist, US Department \\ of Agriculture-Animal and Plant Health Inspection Service-Wildlife Services, National Wildlife Research Center, 4101 LaPorte Ave, Fort Collins, CO \\ 80521, USA; ${ }^{3}$ Professor, School of Natural Resources, University of Arizona, Tucson, AZ 85721, USA; ${ }^{4}$ Professor, Wildlife Program, College of Forestry \\ and Conservation, University of Montana, Missoula, MT 59812, USA; and ${ }^{5}$ Arizona State Director, US Department of Agriculture-Animal and Plant \\ Health Inspection Service-Wildlife Services, 8836 N 23 Avenue, Suite 2, Phoenix, AZ 85021, USA.
}

\begin{abstract}
Vigilant behavior in wild ungulates is critical to guard against predation. However, few studies have examined vigilant behavior in domesticated ungulates. Considering the expansion of large predator populations, understanding vigilant behavior and factors that influence it will help with the management of livestock. We observed adult female cattle (Bos taurus L.) in open-range conditions where large predators (wolves [Canis lupus L.] and mountain lions [Puma concolor (L.).]) were common threats during summers of 2005 and 2006 in eastern Arizona. This study was designed to determine 1) to what extent cattle exhibit vigilant behavior compared to published data on wild ungulates, 2) whether predation events influence vigilance rates of cattle, and 3) whether social and environmental factors affect vigilance of cattle. Cattle exhibited vigilant behavior $(3 \% \pm 0.19 \%)$ during peak foraging periods, but at a lower rate than wild ungulates. Cows with calves were more than twice as vigilant $(4.5 \% \pm 0.46 \%)$ as those without calves $(2.0 \% \pm 0.27 \%)$. Single cattle and groups of two to five exhibited higher vigilance rates $(4.2 \% \pm 0.79 \%)$ than groups of six to $20(2.5 \% \pm 0.32 \%)$ and groups of $>20$ $(3.0 \% \pm 0.41 \%)$. Cattle in groups of $>20$ increased vigilance as visual obstruction increased. Mother cows whose calves were preyed upon $(n=5)$ exhibited a $3 \%$ to $48 \%$ increase in vigilance within $3 \mathrm{~d}$ after their calves were killed; this rate returned to near baseline levels after $10 \mathrm{~d}$. Conversely, mother cows reduced foraging after their calves were killed from $88.5 \% \pm 1.69 \%$ to $43.5 \% \pm 11.4 \%$; foraging rate also returned to near baseline levels after $10 \mathrm{~d}$. Cattle exhibit vigilance at lower levels compared to wild ungulates, but this behavior appears to be at least partially an antipredatory behavior. Our findings provide support that predators can influence cattle behavior.
\end{abstract}

\section{Resumen}

El comportamiento de vigilancia en ungulados silvestres es crítico para protegerse contra los depredadores. Sin embargo, pocos estudios han analizado el comportamiento de vigilancia en ungulados domésticos. Considerando el incremento de la población de grandes depredadores, comprender el comportamiento de vigilancia y los factores que influyen en él, ayudará en un mejor del manejo del ganado. Nosotros observamos vacas adultas (Bos taurus L.) en libre pastoreo, donde grandes depredadores (Lobos [Canis lupus L.] y leones de montaña [Puma concolor (L.).]) fueron amenazas comunes durante el verano de 2005 y 2006 al oriente de Arizona. Este estudio fue diseñado para determinar 1) El numero de animales en el hato que exhibe comportamiento de vigilancia, comparando con datos publicados sobre ungulados salvajes, 2) si los eventos de predación influencian en la tasa de vigilancia del ganado, y 3) si factores sociales y medioambientales afectan la vigilancia del ganado. El ganado exhibió comportamiento vigilante $(3 \% \pm 0.19 \%)$ durante periodos pico de pastoreo, pero en una proporción menor que los ungulados salvajes. Vacas con becerro estuvieron alertas mas del doble $(4.5 \% \pm 0.46 \%)$ que vacas sin becerro $(2.0 \% \pm 0.27 \%)$. El ganado solitario y en grupos de dos a cinco exhibieron mayores tasas de vigilancia $(4.2 \% \pm 0.79 \%)$ que grupos de ganado de seis a 20 animales $(2.5 \% \pm 0.32 \%)$ y grupos de mas de $20(3.0 \% \pm 0.41 \%)$. El Ganado en grupos $>20$ incrementó la vigilancia conforme se incrementó la obstrucción visual. Vacas madres de becerros que fueron víctimas de depredación $(n=5)$ tuvieron un incremento de 3\% a $48 \%$ en tiempo de vigilancia dentro de los 3 días después de que sus becerros fueron sacrificados; esta tasa de vigilancia regresó a los niveles normales después de 10 días. En contraste, las vacas madres redujeron su pastoreo después de que sus crías fueron sacrificadas $88.5 \% \pm 1.69 \%$ a $43.5 \% \pm 11.4 \%$; los patrones de pastoreo también regresaron a los niveles normales después de 10 días. El ganado exhibe una vigilancia menor, comparado con ungulados silvestres, pero este comportamiento parece ser parcialmente contra la predación. Nuestros resultados apoyan la idea de que los predadores pueden influenciar el comportamiento del ganado.

Key Words: foraging behavior, group size, herbivore, lactation status, predators, ungulate

Funding for this research was provided by the Arizona Game and Fish Department, US Department of Agriculture-Animal and Plant Health Inspection Service-Wildlife Services, and T\&E, Inc.

Mention of a proprietary product does not constitute a guarantee or warranty of the product by the authors and does not imply its approval to the exclusion of other products that also might be suitable.

At the time of the research, Kluever was a Graduate Assistant at the School of Natural Resources, University of Arizona, Tucson, AZ.

Correspondence: Bryan M. Kluever, Hayden-Wing Associates, 2308 South 8th Street, Laramie, WY 82072, USA. Email: bmkluever@yahoo.com

Manuscript received 3 August 2007; manuscript accepted 3 February 2008.

\section{INTRODUCTION}

Understanding the impact of predators on livestock is often critical for the economic solvency of livestock producers (Naughton-Treves et al. 2003; Schiess-Meier et al. 2007; Schwerdtner and Gruber 2007) and for efforts to recover endangered predators such as wolves (Mech 1995; Musiani et al. 2003; Bradley and Pletscher 2005; Harper et al. 2005). In almost all cases, the impact of predators on livestock is measured in terms of the number of livestock killed (Stahl et al. 
2001; Treves et al. 2002; Oakleaf et al. 2003, Breck and Meier 2004), but mortality events might not be the only impact that predators have on livestock. In native ungulates many studies have shown that predators have important indirect impacts that can have important implications for prey behavior (Hunter and Skinner 1988; Laundré et al. 2001, Lung and Childress 2006) and ecosystem functioning (Ripple and Larsen 2000; Ripple and Beschta 2003, 2007).

Considering this important aspect of predation, we found it surprising that no field studies have investigated the indirect impact of predators on domestic livestock. Several studies have focused on responses of livestock to predators in pen studies (Terlouw et al. 1998; Hansen et al. 2001; Welp et al. 2004). These studies have revealed behavioral responses, but it is unknown whether predators impact the behavior of cattle on the range and, if so, whether changes in behavior have any consequences for livestock producers. If cattle are found to forage more efficiently (i.e., spend less time scanning their environment and more time foraging) in certain areas or conditions, it could be beneficial to manage for those conditions to increase forage efficiency. Conversely, cattle that regularly scan their environment might sacrifice foraging efficiency but be more likely to detect predators and thus reduce the risk of predation.

Many studies that focus on indirect impacts of predators on ungulates focus on scanning behavior, or vigilance (Cameron and Du Toit 2005; Du Toit and Yetman 2005; Loehr et al. 2005; Lung and Childress 2006) because the primary function of vigilance appears to be detection and avoidance of predators (Pulliam 1973; Diamond and Lazarus 1974; Lima 1987; Quenette 1990; Hunter and Skinner 1998; Boland 2003). Vigilance increases in wild ungulates following the reintroduction of a predator species (Hunter and Skinner 1998; Laundré et al. 2001). For several ungulates, vigilance also increases after the birth of young (Turner 1979; Lipetz and Bekoff 1982; Underwood 1982; Schall and Ropartz 1985; Lung and Childress 2006), but this relationship is not always confirmed (Ruckstuhl and Festa-Bianchet 1998; Ruckstuhl et al. 2003).

Vigilance in prey animals can be influenced by social and environmental factors other than the presence of predators or predation events, although many of these might be correlated with predation risk (Lung and Childress 2006). For some gregarious ungulates, vigilance of individual animals decreased as group size increased (Quenette 1990), but this trend is not always apparent (Elgar 1989). Trees and shrubby vegetation can hamper ungulates' ability to scan their environment, causing an increase in vigilance. For example, mule deer (Odocoileus hemionus Raf.) were more vigilant in forested areas compared to open areas (Hernandez et al. 2005) and were more vigilant at forest edges, an area where they might have been more susceptible to mountain lion (Puma concolor [L.]) predation, than within open and forest areas (Altendorf et al. 2001). Other studies reveal varying results on the effects of habitat on vigilance of ungulates (Underwood 1982; Schall and Ropartz 1985; Lagory 1986).

Domestic cattle (Bos taurus L.) and other large ungulates are exposed to a host of social and environmental factors that can influence foraging behavior. However, none of the aforementioned factors that influence vigilance in wild ungulates have been researched in free-ranging domestic cattle. Information is

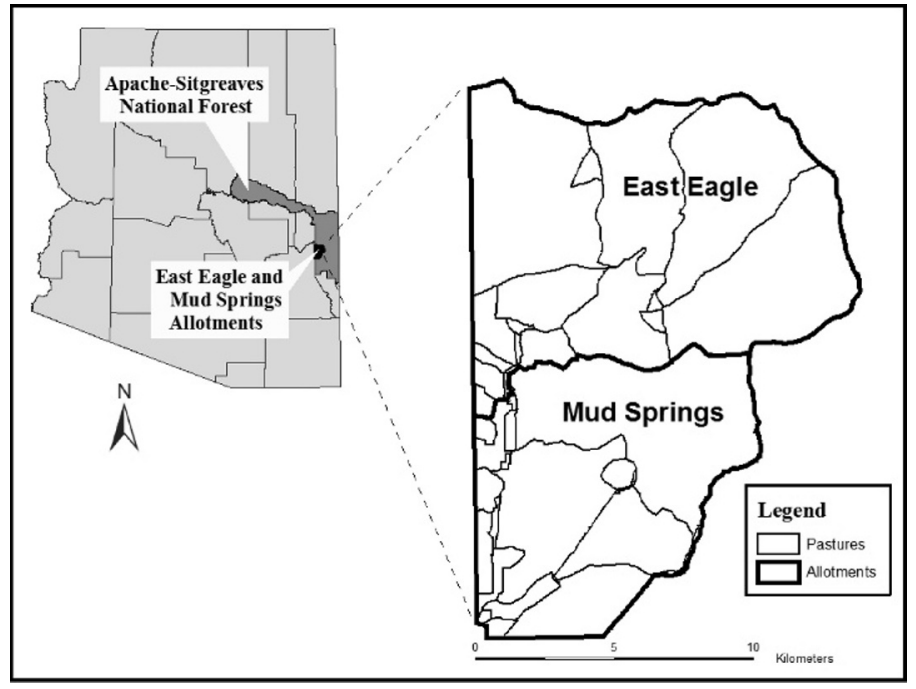

Figure 1. Map of Arizona showing location of study site within the Apache-Sitgreaves National Forest (data courtesy of US Forest Service).

sparse on the indirect effects of predation on foraging behavior of cattle (Howery and DeLiberto 2004), but there are logical reasons to speculate that response to predators by domestic livestock could differ from wild ungulates due to domestication (Price 1999; Berger and Person 2001). Our objectives in this study were to determine 1) to what extent cattle exhibit vigilant behavior compared to published data on wild ungulates, 2) whether predation events influence vigilance rates of cattle, and 3) whether social and environmental factors affect vigilance of cattle.

\section{MATERIALS AND METHODS}

\section{Study Site}

The study was conducted in the East Eagle (EEA) and Mud Springs (MSA) grazing allotments within the Apache-Sitgreaves National Forest of northeastern Arizona (lat $32^{\circ} \mathrm{N}$, long $\left.109^{\circ} \mathrm{W}\right)$. The EEA and MSA grazing allotments encompass approximately 30000 ha, range in elevation from 1500 to $2600 \mathrm{~m}$, and contain mostly steep and rugged topography, ranging from thickly timbered areas to open meadows (Fig. 1). Vegetation on the EEA and MSA is composed primarily of a mosaic of ponderosa pine (Pinus ponderosa P. \& C. Lawson) forest and pinyon pine ( $P$. edulis Engelm.)-alligator juniper (Juniperus deppeana Steud.) woodland. Other woody species include gray oak (Quercus grisea Liebm.), silverleaf oak (Q. bypoleucoides A. Camus), Gambel oak (Q. gambelii Nutt.), and honey mesquite (Prosopis glandulosa Torr.). Dominant grass species in more open areas of the allotments include sideoats grama (Bouteloua curtipendula [Michx.] Torr.), blue grama (B. gracilis ex Kunth.), hairy grama (B. hirsuta Lag.), purple grama (B. radicosa [Fourn.] Griffiths), sprangle top (Leptochloa spp. Beauv.), and Lehmann lovegrass (Eragrostis lehmanniana Nees). The EEA and MSA are adjacent to each other and are similar in vegetation, though the MSA is less variable in topography and consists of more open grassy areas. 


\section{Predators}

Mexican wolves (Canis lupus L. subsp. baileyi) have been present in the area at various densities since 1998. This area also contained 1.3 to 2.6 mountain lions $\cdot \mathrm{km}^{-2}$ (Arizona Game and Fish Department, unpublished data, 2007), 1.3 to 2.6 black bears $\cdot \mathrm{km}^{-2}$ (Ursus americanus Pallas; Arizona Game and Fish Department, unpublished data, 2007), and an unknown number of coyotes (Canis latrans Say). Two adult cattle were attacked by predators in 2005-2006; however, observed predation loss of calves was about $5 \%$ annually from 2003-2006.

\section{Behavioral Observations}

We observed 213 Angus-Hereford cross-bred cows between 12 May and 2 August of both 2005 and 2006. This time frame encompassed the entire summer cattle grazing season on our study area. Approximately 300 head of Angus-Hereford crossbred cattle grazed the allotments during both years of the study. Sixty-eight percent of the cows observed were in the EEA grazing allotment and $32 \%$ were in MSA. Both grazing allotments are divided into several pastures. All data were collected in the Robinson Mesa (370 ha, 8\% of observations) and Malay (3515 ha, 24\% of observations) pastures of the EEA, and the Southwest (1 135 ha, $57 \%$ of observations) and Big (1 070 ha, $17 \%$ of observations) pastures of the MSA.

We used spotting scopes (Swarovski STS 65; Swarovski Optik North America, Cranston, RI) and binoculars (Swarovski SLC $10 \times 42$ ) to make observations on adult cows. Individual cows and calves were readily identified by ear tags. Cow-calf pairs were confirmed by observing suckling and developing a list of cow-calf pairs using ear tags as the primary identifying characteristic. We did not collect foraging behavior on any adult cow for more than one sampling period unless its calf was killed by predators. Cows $>1.5$ y old were considered adults. Animals $<6$ mo old and between 6 and 18 mo of age were considered calves and yearlings, respectively, and were not sampled. We used focal animal sampling (Altman 1974) to gather data on individual cows. Sampling units were defined as focal animal observation periods lasting $10 \mathrm{~min}$ during which an animal's behavior was recorded every $15 \mathrm{~s}$ for a total of 40 scans per observation ( $n=8520$ total scans). Sampling took place between 0500-0900 hours and 1700-2100 hours. These times coincided with peak foraging hours of domestic ungulates during summer in the western United States. (Marlow and Pogacnik 1986; Howery et al. 1996; Porath et al. 2002). We located cattle by systematically hiking or driving on trails in the pasture wherecattle were grazing. Once a group of cows was located, we assigned each adult a number and randomly selected a focal animal to sample. To avoid observer fatigue, we sampled no more than three animals within $1 \mathrm{~h}$. Distances from observer to cattle typically ranged from 50 to $200 \mathrm{~m}$. Observation periods during which a focal animal's behavior was interrupted through detection of an observer were rare and not included in our analyses. An observer was considered detected if a cow exhibited vigilant behavior toward the general direction of the observer for $\geq 3$ scans of the observation period. Calves were not always in the same group as their mother but were typically observed with her when re-observed at a later time.
Cow behavior was divided into five categories that were immediately discernible at $15 \mathrm{~s}$ scan intervals: foraging, scanning, traveling, standing/not scanning, and resting. Foraging was defined as standing or walking slowly with the head below shoulder level. Scanning was defined as standing with the head at or above shoulder level. Traveling was defined as walking, trotting, or running with the head at or above shoulder level. Standing/not scanning was defined as nursing, licking, or scratching. Resting was defined as any behavior that took place while an animal was lying down. Scanning behavior was our estimate of vigilance. Vigilance has been defined in previous studies with wild ungulates as when an animal stands with its head raised while looking around, and is not lying, feeding, moving to another feeding spot, or engaged in a maintenance behavior (e.g., grooming or nursing; Hunter and Skinner 1998; Laundré et al. 2001). Based on our definition, animals could have been engaged in activities other than vigilance while scanning (e.g., chewing, ruminating, monitoring calves and other herd mates). This definition has been the most common metric used to measure vigilant behavior in wild ungulates (Lung and Childress 2006).

To determine factors that affected vigilance, we quantified the following variables during or immediately after each sampling effort: group size (1-5 animals, 6-20 animals, $>20$ animals), percentage of visual obstruction, slope $(\leq 5$ or $>5 \%$ ), lactation status (with or without calf), and group type (with or without calves). A group was defined as an aggregation of cattle with a nearest neighbor distance of $\leq 100 \mathrm{~m}$ from the randomly selected focal animal. Individuals located $>100 \mathrm{~m}$ from the focal animal at the onset or conclusion of sampling were not considered part of the group. Percent visual obstruction near eye level of cattle $(1.5 \mathrm{~m})$ was quantified using a modified line-intercept method (Canfield 1941). Woody vegetation $\leq 3 \mathrm{~m}$ of either side of a $30 \mathrm{~m}$ tape placed where animals were centrally observed foraging was considered visual obstruction. Percent visual obstruction was calculated by dividing the length of woody vegetation that intercepted the $\leq 3 \mathrm{~m}$ buffer of the 30-m tape with the length that did not contain woody vegetation. If an animal was moving while foraging, we sampled woody vegetation in the area the focal animal had spent the majority of its time during the 10-min observation period. Our rationale for measuring visual obstruction was that it was a better metric than canopy cover when measuring vigilance rates. Cattle are likely to be more influenced by the architecture and thickness of vegetation at eye level rather than above or below their line of sight. Slope was measured using an inclinometer (Silva Ranger 15CL, Fiskars Corporation, Madison, WI).

\section{Verification of Predation}

All calves within the study area were fitted with radio transmitters that emitted a mortality signal if transmitters remained still for $4 \mathrm{~h}$. Radio signals were checked daily and calf mortalities caused by predators that took place during summers of 2005 and 2006 were located by study personnel using radio telemetry. Mortalities were confirmed by United States Department of Agriculture-Animal and Plant Health Inspection Service-Wildlife Services personnel and linked to mother cows via ear tags and calving records. We conducted field 
necropsies to determine cause of death based on condition of the carcass, presence or absence of wounds and subcutaneous hemorrhaging, blood trails, signs of struggle, and evidence of predators such as tracks, scat, predator-specific wounds, canine spacing, and distinctive consumption patterns (Roy and Dorrance 1976). We were unable to locate all calf mortalities in time to determine cause of death.

\section{Statistical Design}

We used a before-after/control impact (BACI) design (Green 1979; Morrison et al. 2001) to evaluate the influence of predation-caused calf mortalities on vigilance behavior of cows. In the BACI design, vigilance observations are made before and after a predation event. If predation influenced vigilance in mother cows in our study, we expected it to appear as an interaction between the difference in mean vigilance rates during the "impact" and "reference" periods, i.e., before and after a predation event (Morrison et al. 2001). Two control periods for our study were $>1 \mathrm{wk}$ prior and 10 to $12 \mathrm{~d}$ following a predatory event. The impact period was $0-3 \mathrm{~d}$ immediately after a predation event. Because we did not know when predation events would take place, our initial "reference" period could not be controlled and ranged from 5 to $27 \mathrm{~d}$ before the predation event. The 0-3 d "impact" period was established because some predation events were not immediately detected and several mother cows took 1 to $2 \mathrm{~d}$ to relocate. Our second "reference" period of 10 to $12 \mathrm{~d}$ was established because this time frame was the maximum number of days it took to relocate an animal. For the BACI design, we limited our sampling to mothers who had experienced confirmed predation events on their calves. We assumed that mothers of calves killed were in the vicinity of the predation event. Sampling procedures for mother cows whose calves were preyed upon was identical to previous sampling, except these animals were specifically targeted for additional sampling rather than being randomly selected.

Mother cows might show an increase in vigilance whenever their calves are missing, regardless of the cause. Thus, we also compared vigilance rates of cattle whose calves were alive but temporarily missing to those that were missing due to a predation event. We were able to determine if a calf was missing by scanning the group and noting the individuals within a group. If a calf was missing, but seen with her mother at a later date, the calf was classified as temporarily missing but alive.

\section{Statistical Analyses}

Social and environmental data were analyzed using the GENMOD procedure (SAS version 9.1.3). The response variable was percent time vigilant, which can be considered a rate variable. Therefore, we initially modeled the response variable using a Poisson distribution, but because of overdispersion in the variance, we fit a negative binomial regression model. We log-transformed scanning data to meet the assumptions of this model. The main effects (explanatory variables) included percent visual obstruction, lactation status (with or without a birthed calf), group size, slope, and group type. All main effects were categorical except for visual obstruction, which was continuous. One explanatory variable,

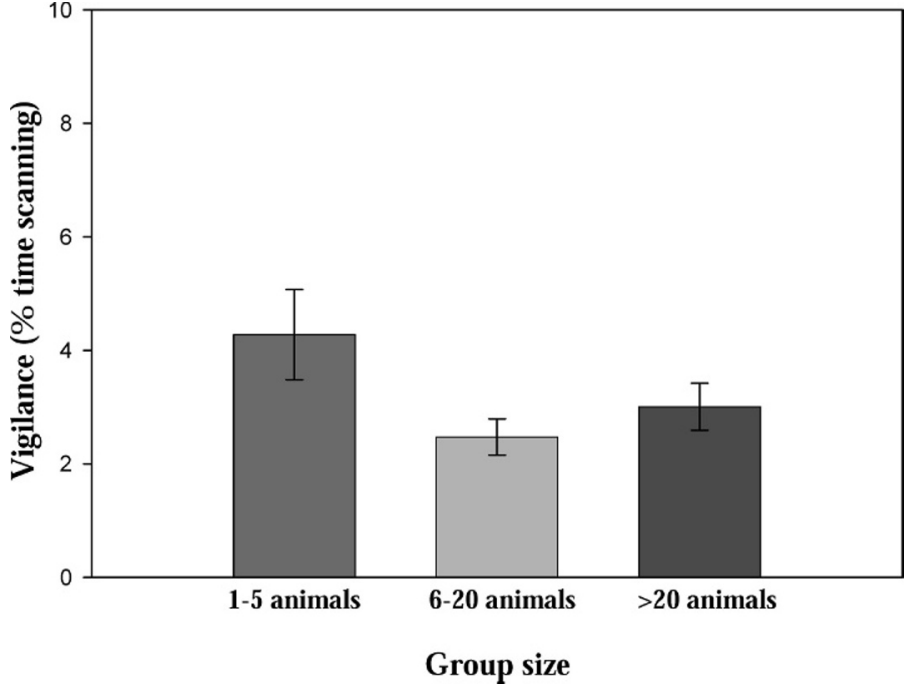

Figure 2. Percent of time $(\bar{X} \pm \mathrm{SE})$ adult female cattle exhibited vigilance during peak foraging hours in relation to group size. Group sizes were $1-5$ animals $(n=32), 6-20$ animals $(n=98)$, or $>20$ animals $(n=84)$

group size, had multiple categories $(n=3)$ and we used linear contrasts to test for differences among categories. We analyzed interactions involving all possible combinations of main effects. Explanatory variables were considered significant at a probability of $P<0.05$. We analyzed BACI data $(n=5$ predation events; four mountain lion, one wolf) using a Friedman twoway analysis where we blocked for cow. We compared vigilance of cattle whose calves were missing and alive $(n=13)$ with cows whose calves were preyed upon $(n=5)$ after $0-3 \mathrm{~d}$ and $10-12 \mathrm{~d}$ following a predation event using a one-way analysis of variance (two separate analyses).

\section{RESULTS}

We report results as percent arithmetic means \pm standard error. Overall, all cows allocated $3.0 \% \pm 0.19 \%$ of their time to vigilant behavior, $86 \% \pm 1.35 \%$ to foraging, $3.8 \% \pm 0.55 \%$ to traveling, $2 \% \pm 0.8 \%$ to resting, and $4.9 \% \pm 0.74 \%$ to standing/not scanning during peak foraging hours. Slope and whether or not a group contained calves did not affect vigilance $(P>0.05)$. Vigilance levels were influenced by lactation status $\left(\chi^{2}=20.56, \mathrm{df}=1, P<0.001\right)$. Vigilance rate of cows with calves $(4.5 \% \pm 0.46 \%, n=130)$ was over twice that of cows without calves $(2.0 \% \pm 0.27 \%, n=84)$. Cattle were more vigilant in the smallest groups (i.e., $1-5$ ) than in groups of 6-20 or groups of $>20\left(\chi^{2}=7.32, \mathrm{df}=2, P=0.0256\right.$; Fig. 2$)$. Cattle in groups $>20$ animals showed a positive relationship between vigilance and visual obstruction $\left(\chi^{2}=15.63, \mathrm{df}=2, P=0.018\right.$; Fig. 3). Otherwise visual obstruction was not an important explanatory variable $(P>0.05)$.

Vigilance of cattle was not consistent after calves were killed by predators $(\mathrm{Q}=10.0, \mathrm{df}=2, P \leq 0.067)$. Vigilance of mother cows before losing calves to predation $(n=5)$ was similar to levels for all other cattle observed $(3.5 \% \pm 0.22 \%$ vs. $3.0 \% \pm 0.19 \%$, respectively). Similarly, mother cows before losing calves foraged at a similar rate when compared to other 


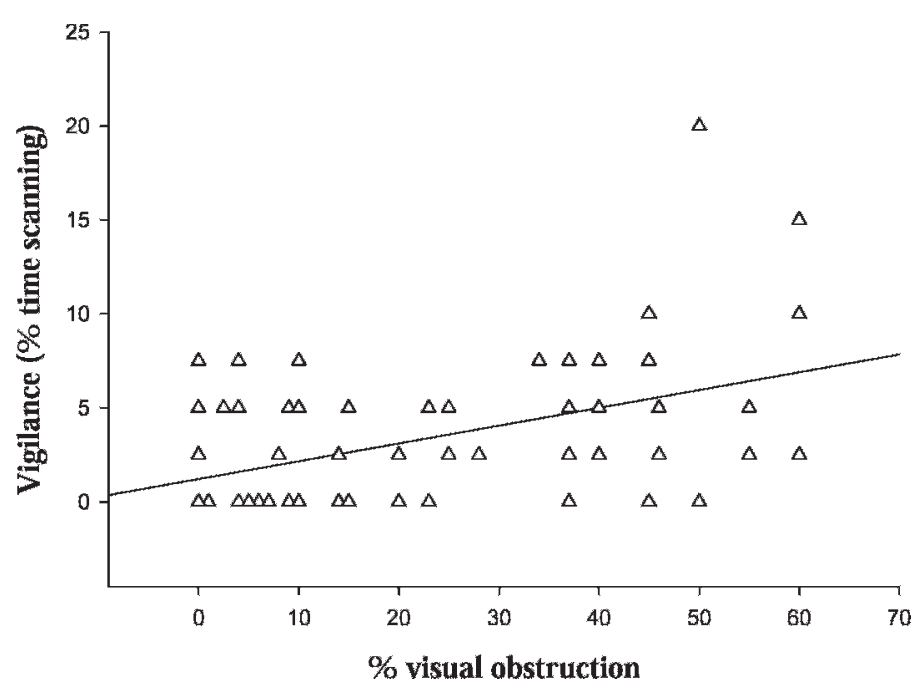

Figure 3. Percent of time $(\bar{x} \pm \mathrm{SE})$ adult female cattle exhibited vigilance during peak foraging hours in relation to the interaction between visual obstruction and groups of $>20$ animals $(n=89)$. Parameter estimates for interactions between visual obstruction and the other two group sizes (i.e., 1-5 or 6-20 animals) were not significant $(P>0.158)$.

observed cattle $(86.0 \% \pm 1.35 \%$ vs. $88.5 \% \pm 1.69 \%)$. However, mother cows whose calves were killed increased vigilance from $3 \%$ to $48 \%$ within $3 \mathrm{~d}$ after a predation event on their calf (Fig. 4). Conversely, mother cows reduced foraging during this time period from $89 \%$ to $44 \%$ (Fig. 4). Mean vigilance by mother cows had returned to near baseline levels within $10 \mathrm{~d}$ following predation events (4\% vs. $8 \%$ ). A similar approach to baseline levels was found for foraging rates of mother cows ( $88 \%$ vs. $89 \%$ ).

Mother cows whose calves were alive but not observed near their mothers, were vigilant $5.1 \% \pm 0.52 \%$ of the time. We were unable to quantify how long these calves had been out of sight from their mothers. We did, however, document that these calves were alive because they were confirmed with their respective mothers the next time they were observed. Mother cows whose calves were killed exhibited much higher vigilance rates for 0-3 d compared to mother cows whose calves were merely missing but still alive $\left(F_{1,16}=32.8, P<0.001\right)$. After 10-12 d following a predation event, mother cows who had lost their calves to predation exhibited similar vigilance levels to mother cows whose calves were missing but alive $\left(F_{1,16}=3.13, P=0.2108\right)$.

\section{DISCUSSION}

\section{Comparison of Vigilance with Wild Ungulates}

Adult female cattle in our study site exhibited lower baseline vigilance rates $(\sim 3 \%)$ than studies with female wild ungulates while actively foraging. For example, vigilance in bison (Bison bison [L.].) ranged from 9.6\% to $18.9 \%$ (Laundré et al. 2001), whereas African buffalo (Syncerus caffer Sparrman) ranged from $4.2 \%$ to $5.6 \%$ (Underwood 1982). Vigilance in female elk (Cervus elaphus L.) varied from $12 \%$ to $30 \%$ (Laundré et al. 2001), whereas giraffe (Giraffa camelopardalis [L.]) scanned their environment at a rate of $18 \%$ to $25 \%$ while actively

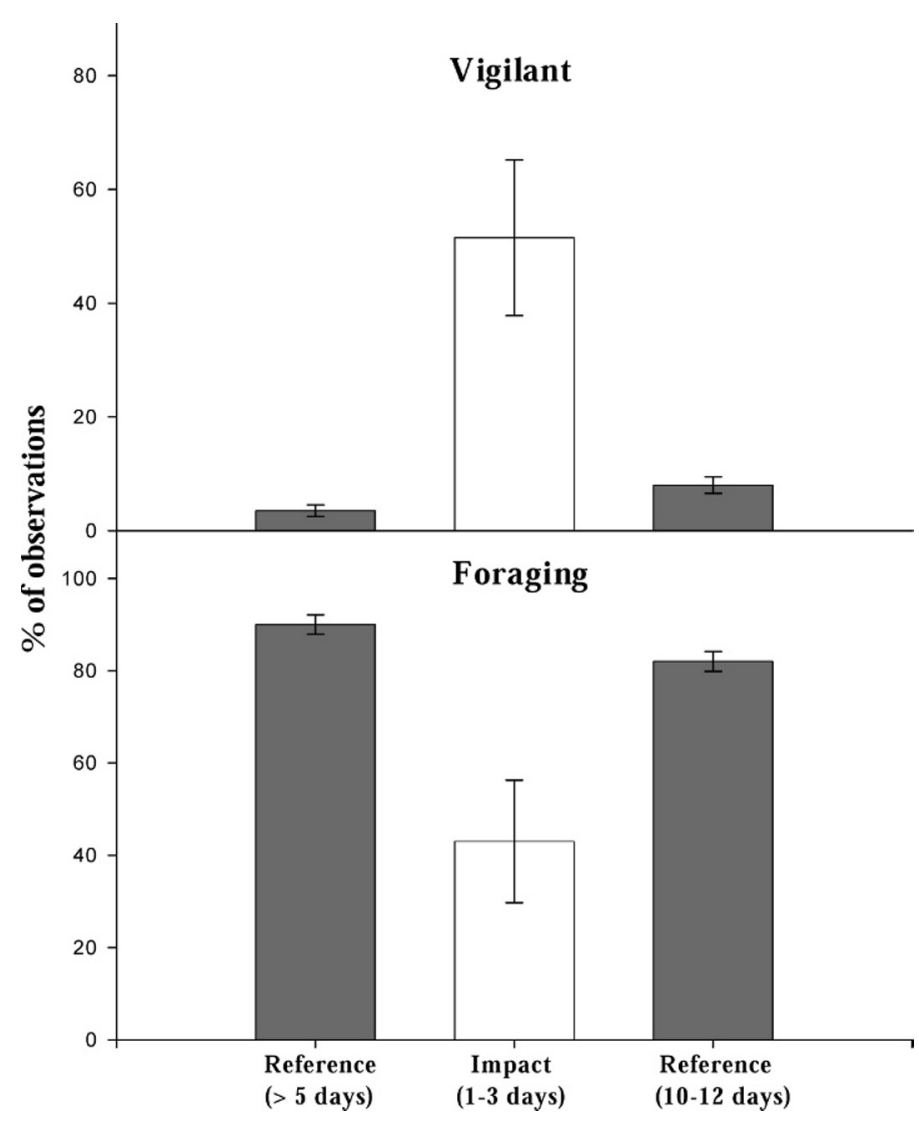

Figure 4. Effect of calf predation ( $n=5$; four mountain lion, one wolf) on percent of time $(\bar{x} \pm \mathrm{SE})$ that mother cows were vigilant or foraging during peak foraging hours. The first reference period was at least 1 wk before predation. The second reference period was $10+d$ after predation. The impact period was 1-3 d following predation.

foraging throughout the day (Cameron and Du Toit 2005). Comparison with wild ungulates from our study area would be more appropriate but such findings have not been published.

Vigilance rates of cattle in our study would likely have been higher if sampling had taken place at times other than peak foraging hours (i.e., midday while cattle are resting). However, differentiating between "vigilance" and "standing while ruminating" would have been difficult during these times. For this reason, we limited our sampling to peak foraging hours. Further, wild ungulates typically have less defined grazing periods than cattle, which allowed wildlife researchers to sample vigilant behavior throughout the day during active foraging bouts.

The reason for lower vigilance rates in cattle is unknown but is likely due to the process of domestication, although it is also possible that species in the genus Bos have inherently lower vigilance. Unfortunately this is a difficult issue to resolve because cattle's wild ancestor, the auroch (Bos primigenius Bojanus), is extinct (Van Vuure 2005). Related species in the Bos genus, such as the gaur (Bos frontalis Hamilton Smith), banteng (Bos banteng Wagner), kouprey (Bos sauveli Urbain), and wild yak (Bos grunniens [L.]) are rare (Nowak 1999), and we are not aware of any studies conducted to examine vigilance rates of these animals. It is important to note that cattle in our study were observed only during peak foraging hours. Vigilance 
levels in cattle might have been higher if we observed cattle during all daylight hours.

Our results show that vigilance behavior in cattle is plastic; cattle in our study adjusted their level of vigilance depending on a variety of factors (discussed below). This plasticity demonstrates the adaptability of behavior in cattle. Because we studied cattle in areas where large carnivores are present and prey on cattle, it is possible that the vigilance rates we documented could be higher than in areas where livestock predation rates are lower.

\section{Reproductive Status}

Lactating cows exhibited higher vigilance rates than those not lactating. This was evident despite the fact that daily dry matter intake of a lactating cow is, on average, $19 \%$ greater than that of a dry cow (National Research Council 1996). This result agrees with previous findings on several wild ungulate species (Lipetz and Bekoff 1982; Underwood 1982; Schaal and Ropartz 1985; Burger and Gochfield 1994; Lung and Childress 2006), although lactation status apparently does not influence vigilance rates in all ungulate species (Haviernick 1996; Ruckstuhl and Festa-Bianchet 1998; Ruckstuhl et al. 2003; Cameron and Du Toit 2005). Lactating cows might compensate for increased vigilance by foraging longer each day, increasing their bite rate, selecting higher quality foods and habitats, or some combination of these factors, but they can engage in these strategies only up to a point (MacWhirter 1991; Ruckstuhl and Festa-Bianchet 1998). Only observing cattle in the morning and evening, as was done in our study, prevents a complete understanding of how cattle respond to higher vigilance rates during typical grazing periods. Additional research on foraging and vigilance behavior of cattle throughout the day (i.e., activity budgets) is needed.

Vigilance rates of lactating mammalian females decreases as the age of young increases (Leighton-Shapiro 1986; Caro 1987). This relationship has not been examined in large herbivores but it seems plausible that a similar trend would be expected. Generally, susceptibility to predation in ungulates is reduced as age (up to a point) and body size increase (Underwood 1982). Moreover, as young ungulates age, they gradually obtain more of their nutrients from forage species than from mother's milk (Schmidt-Nielsen 1990). We did not examine the influence of age of calves on vigilance in cattle because calving took place throughout the sampling period and exact ages of calves were not always known.

\section{Predation of Calves}

Mother cows whose calves were killed by predators increased vigilance and decreased foraging rates immediately following a predation event. Vigilance rates in these cows were $>10$ times higher than mother cows temporarily separated from their calf. We assumed that mothers were present, or at least in the vicinity, when their calf was preyed upon. Ungulates elevate vigilance levels after the translocation of a large carnivore species into the area (Hunter and Skinner 1998; Laundré et al. 2001). Increases in individual acts of predation are the likely cause for such an increase. Our study did not examine whether the translocation of predators influenced vigilance, but cattle that lost their calves to predators showed a dramatic behavioral response. Our study would have been bolstered if we could have compared vigilance of mother cows that lost calves to other forms of mortality (i.e., disease) with those lost to predation. However, even if mother cows reacted similarly to all forms of calf mortality, predation of calves would contribute to elevated vigilance levels of the entire herd if vigilance due to predation mortality is additive (see Mrlík 1998). There might be important differences between predators (e.g., lions vs. wolves) in the indirect impact they have on cattle and other ungulates. Chasing/harassing predators might increase vigilance rates of entire groups of prey species compared to stalking/ambushing predators. Understanding these differences could be important for livestock management practices.

\section{Group Size and Vegetation Obstruction}

Group size influenced vigilance of cattle. Groups of $>5$ animals displayed lower vigilance rates than smaller groups of one to five animals. These findings correspond with the majority of wild ungulate studies (Elgar 1989; Quenette 1990; Lima and Dill 1990; Lung and Childress 2006). Conversely, some research has not found group size to influence this behavior or has found vigilance to actually increase with group size (Molvar and Bowyer 1994; Cameron and Du Toit 2005). Our results support the idea that individual animals benefit from the collective scanning effort of group members (Pulliam 1973).

Cattle in groups of $>20$ animals showed a slight increase in vigilance as visual obstruction increased, but this relationship was not evident for cattle in smaller groups. Despite statistical significance, caution should be taken when speculating on the biological significance of this finding, due to the weak relationship (Fig. 4). If the primary function of vigilance is predator detection (Pulliam 1973; Lima 1987), it would seem logical that increased woody vegetation would increase vigilance for cattle of all group sizes, because the ability to scan for predators would be hampered by woody vegetation. The interaction between group size and visual obstruction might indicate an increase in social vigilance as group size and visual obstruction increases. Mother cows in larger groups in thicker cover might elevate vigilance to keep track of their calves and other herd mates (Beauchamp 2001). Conversely, cattle in smaller groups might not elevate vigilance as woody cover increases because these groups have fewer conspecifics to monitor. In addition, increases in woody vegetation are correlated with lower levels of herbaceous forage that could also result in a decrease in foraging behavior and an increase in scanning behavior. Competition for forage is also more likely in larger groups. Cattle in large groups might scan the environment at a higher rate to track suitable food patches (Roberts 1996). These hypotheses warrant further research to test their validity.

\section{MANAGEMENT IMPLICATIONS}

Our study suggests that cattle react to predators in a similar fashion to wild ungulates, although overall vigilance levels were somewhat lower than in wild ungulates. Lactation status, group size, and visual obstruction apparently interact across space and time to influence vigilance and foraging behavior of 
free-ranging cattle. Cattle vigilance rates might be biased low in our study compared to published wild ungulate studies because observations were only collected during peak foraging hours. Vigilance in mother cows was strongly influenced by actual predation events (at least in the short term). Although our results regarding predation are significant, our "predation event" sample size was small $(n=5)$ and our overall results only correspond to cattle behavior during peak foraging hours. Future studies are needed that could verify our results regarding predation and account for vigilance rates during all periods of the day (i.e., activity budgets).

Reducing predation of calves by predators will reduce the number of herd members that increase vigilance levels and ostensibly increase foraging and intake rates. However, our study did not address whether foraging and vigilance behavior of cows other than those that lost their calves during predation events were affected by predation events. Further, our study was not designed to address whether changes in vigilance indirectly impacted production levels in cattle. Productivity of wild and domestic ungulates is largely a function of nutrient intake. Therefore, further research (i.e., observational studiesactivity budgets, manipulative experiments, conceptual modeling) is needed to quantify whether vigilance in cattle influences foraging, and if so, to what extent. Further research should focus on the potential and actual indirect impacts of predators on vigilance of cattle, as well as other environmental and social factors not addressed in this study (i.e., position in herd, age of cattle, male vs. female, vegetation type, animal productivity).

\section{ACKNOWLEDGMENTS}

G. F. Fornara, S. M. Smith, and J. M. Timmer were invaluable field assistants. M. C. Borgstrom and B. J. Steidl provided statistical counseling. C. D. Carrillo and T. B. Veenendaal, US Department of Agriculture-Animal and Plant Health Inspecion Service-Wildlife Services, provided essential logistical support. J. B. Juarez and G. C and D. A Ely provided uninterrupted access to their range cattle. D. Bailey served as a critical reviewer.

\section{LITERATURE CITED}

Altendorf, K. B., J. W. Laundré, A. L. Lopez, and J. S. Brown. 2001. Assessing effects of predation risk on foraging behavior of mule deer. Journal of Mammalogy 82:430-439.

Altman, J. 1974. Observational study of behavior: sampling methods. Behaviour 49:227-267.

Beauchamp, G. 2001. Should vigilance always decrease with group size? Behavioral Ecology and Sociobiology 51:47-52.

Berger, J. S., and J. E. Person. 2001. Recolonizing carnivores and naïve prey: conservation lessons from Pleistocene extinctions. Science 291:1036-1039.

BoLAnd, C. R. J. 2003. An experimental test of predator detection rates using groups of free-living emus. Ethology 109:209-222.

Bradley, E. H., and D. H. Pletscher. 2005. Assessing factors related to wolf depredation of cattle in fenced pastures in Montana and Idaho. Wildlife Society Bulletin 33:1256-1265.

BreCK, S., AND T. Meier. 2004. Managing wolf depredation in the United States: past, present and future. Sheep \& Goat Research Journal 19:41-46.

Burger, J., And M. Gochfield. 1994. Vigilance in African mammals: differences among mothers, other females, and males. Behaviour 131:153-159.

Cameron, E. Z., and J. T. Du Tolt. 2005. Social influences on vigilance behaviour in giraffes, Giraffa camelopardalis. Animal Behaviour 69:1337-1344.
Canfield, R. H. 1941. Application of the line interception method in sampling range vegetation. Journal of Forestry 39:388-394.

Caro, T. M. 1987. Cheetah mothers vigilance-looking out for prey or predators. Behavioral Ecology and Sociobiology 20:351-361.

Diamond, S., and J. Lazarus. 1974. The problem of vigilance in an animal life. Behavioral Ecology 9:60-79.

Du Tolt, J. T., and C. A. Yetman. 2005. Effects of body size on the diurnal activity budgets of African browsing ruminants. Oecologia 143:317-325.

Elgar, M. A. 1989. Predator vigilance and group size in mammals and birds. Biological Review 64:13-33.

Green, R. H. 1979. Sampling design and statistical methods for environmental biologists. New York, NY, USA: Wiley. $250 \mathrm{p}$.

Hansen, I. F., H. S. Christansen, B. Hansen, B. Braasta, and M. Bakken. 2001. Variation in behavioral response of ewes toward predator-related stimuli. Applied Animal Behaviour Science 70:227-237.

Harper, E. K., W. J. Paul, and L. D. Mech. 2005. Causes of wolf depredation increase in Minnesota from 1979-1998. Wildlife Society Bulletin 33:888-896.

HAVIERNICK, M. 1996. La stratégie alimentaire de la chévre de montagne (Oreamnos americanus): eude de l'utilisation de l'habitat et du comportement antiprédateur [thesis]. Sherbrooke, Canada: Université de Sherbrooke. 185 p.

Hernandez, L., J. W. Laundré, and M. Gurung. 2005. From the field: use of camera traps to measure predation risk in a puma-mule deer system. Wildlife Society Bulletin 33:353-358.

Howery, L. D., AND T. J. DeliBerto. 2004. Indirect effects of carnivores on livestock foraging behavior and production. Sheep and Goat Research Journal 19:5357.

Howery, L. D., F. D. Provenza, R. E. Banner, and C. B. Scott. 1996. Differences in home range and habitat use among individuals in a cattle herd. Applied Animal Behaviour Science 49:305-320.

Hunter, L. T. B., AND J. D. SkInner. 1998. Vigilance behavior in African ungulates: the role of predation pressure. Behaviour 135:195-211.

LAGoRY, K. E. 1986. Habitat, group-size, and the behavior of white-tailed deer. Behaviour 98:168-179.

Laundré, J. W., L. Hernandez, and K. B. Altendorf. 2001. Wolves, elk and bison: reestablishing the "landscape of fear" in Yellowstone National Park, U.S.A. Canadian Journal of Zoology 79:1401-1409.

LeIghton-Shapiro, M. E. 1986. Vigilance and the costs of motherhood to rhesus monkeys. American Journal of Primatology 10:414-415.

LIMA, S. L. 1987. Vigilance while feeding and its relation to the risk of predation. Journal of Theoretical Biology 124:303-316.

LIMA, S. L., AND L. M Dill. 1990. Behavioral decisions made under the risk of predation: a review and prospectus. Canadian Journal of Zoology 68:619-634.

Lipetz, V. E., AND M. BeKoff. 1982. Group size and vigilance in pronghorns. Journal of Comparative Ethology 58:203-216.

Loehr, J., M. Kovanen, J. Carey, H. Hogmander, C. Jurasz, S. Karkkainen, J. Suhonen, AND H. YLonen. 2005. Gender and age-class-specific reactions to human disturbance in a sexually dimorphic ungulate. Canadian Journal of Zoology 83:1602-1607.

Lung, M. A., And M. B. Childress. 2006. The influence of conspecifics and predation risk on the vigilance of elk (Cervus elaphus) in Yellowstone National Park. Behavioral Ecology 18:12-20.

MACWHIRTER, R. B. 1991. Effects of reproduction on activity and foraging behavior of adult female Columbian ground squirrels. Canadian Journal of Zoology 69:2209-2216.

Marlow, C. B., ANd T. M. Pogacnik. 1986. Cattle feeding and resting patterns in a foothills riparian zone. Journal of Range Management 39:212-217.

$\mathrm{MeCH}_{\mathrm{E}}$ D. L. 1995. The challenge and opportunity of recovering wolf populations. Conservation Biology 9:270-278.

Molvar, E. M., And R. T. Bowyer. 1994. Costs and benefits of group living in a recently social ungulate: the Alaskan moose. Journal of Mammalogy 75:621-630.

Morrison, M. L., W. M. Block, M. D. Strickland, and W. L. Kendall. 2001. Wildlife study design. New York, NY, USA: Springer Verlag. 210 p.

MrLik, V. 1998. Analysis of factors affecting the number of vigilant individuals in seasonal groups of roe deer. Folia Zoologica 47:13-19. 
Musiani, M., C. Mamo, L. Boitani, C. Callaghan, C. C. Gates, L. Mattei, E. Visalberghi, S. BreCK, AND G. VolpI. 2003. Wolf depredation trends and the use of fladry barriers to protect livestock in Western North America. Conservation Biology 17:1538-1547.

National Research Council. 1996. Nutrient requirements for beef cattle. 6th ed. Washington, DC, USA: National Academy Press. 242 p.

Naughton-Treves, L., R. Grossberg, and A. Treves. 2003. Paying for tolerance: rural citizens' attitudes toward wolf depredation and compensation. Conservation Biology 17:1500-1511.

Nowak, R. M. 1999. Walker's mammals of the world. Baltimore, MD, USA: Johns Hopkins University Press. 1936 p.

OAKLEAF, J. K., C. Mack, and D. L. MurRay. 2003. Effects of wolves on livestock calf survival and movements in central Idaho. Journal of Wildlife Management 67:299-306

Porath, M. L., P. A. Momont, T. Delcurto, N. R. Rimbey, J. A. Tanaka, and M. Mclnnis. 2002. Offstream water and trace mineral salt as management strategies for improved cattle distribution. Journal of Animal Science 80:346-356.

PrICE, E. O. 1999. Behavioral development in animals undergoing domestication. Applied Animal Behaviour Science 65:245-271.

Pulciam, H. R. 1973. On the advantages of flocking. Journal of Theoretical Biology 38:419-422.

QuenetTe, P. Y. 1990. Functions of vigilance behaviour in mammals: a review. International Journal of Ecology 11:801-818.

RIPPLE, W. J., AND R. L. BESCHTA. 2003. Wolf reintroduction, predation risk, and cottonwood recovery in Yellowstone National Park. Forest Ecology and Management 184:299-313.

Ripple, W. J., and R. L. BeschtA. 2007. Hardwood tree decline following large carnivore loss on the Great Plains, USA. Frontiers in Ecology and the Environment 5:241-246.

RiPPLE, W. J., AND E. J. LARSEN. 2000. Historic aspen recruitment, elk, and wolves in northern Yellowstone National Park, USA. Biological Conservation 95:361370.

RoBeRTS, G. 1996. Why individual vigilance declines as group size increases. Animal Behaviour 51:1077-1086.

Roy, L. D., And M. J. Dorrance. 1976. Methods of investigating predation of domestic livestock. Edmonton, Alberta, Canada: Alberta Agriculture. 53 p.
Ruckstuhl, K. E., and M. Festa-Bianchet. 1998. Do reproductive status and lamb gender affect the foraging behavior of bighorn ewes? Ethology 104:941-954.

Rucstuhl, K. E., M. Festa-Bianchet, and J. T. Jorgensen. 2003. Bite rates in Rocky Mountain bighorn sheep (Ovis canadensis): effects of season, age, sex and reproductive status. Behavioral Ecology and Sociobiology $54: 167-173$

SchaAl, A., and P. Ropartz. 1985. Vigilance behavior in fallow deer (Dama dama) in relation age, sex, group size and cover. Comptes Rendus de l'Academie des Sciences Serie III Sciences de la Vie 310:731.

Scheiss-Meier, M., S. Ramsauer, T. Gabanapel0, and B. Köing. 2007. Livestock predation-insights form problem animal control registers in Botswana. Journal of Wildlife Management 71:1267-1274.

Schmid-Nielson, K. 1990. Food and fuel. In: J. B. Duke [ed.]. Animal physiology: adaptation and environment. Cambridge, United Kingdom: Cambridge University Press. p. 130-168.

Schwerdtner, K., and B. Gruber. 2007. A conceptual framework for damage compensation programs. Biological Conservation 134:354-360.

Stahl, P., J. M. Vandel, V. Herrenschmidt, and P. Migot. 2001. Predation on livestock by an expanding reintroduced lynx population: long term and spatial variability. Journal of Applied Ecology 38:674-687.

Terlouw, E. M. C., P. Boissy, And P. Blinet. 1998. Behavioural responses of cattle to the odours of blood and urine from conspecifics and to the odour of faeces from carnivores. Applied Animal Behaviour Science 57:9-21.

Treves, A., R. R. Jurewicz, L. Naughton-Treves, R. A. Rose, R. C. Willging, and A. P. Wydeven. 2002. Wolf depredation on domestic animals in Wisconsin, 1976-2000. Wildlife Society Bulletin 30:231-241.

Turner, D. C. 1979. An analysis of time budgeting by roe deer in an agricultural area. Behaviour 71:246-290.

UndeRWO0D, R. 1982. Vigilance behavior in grazing African antelopes. Behaviour 79:81-107.

Van Vuure, C. 2005. Retracing the aurochs. history, morphology and ecology of an extinct wild ox. Sofia-Moscow, Russia: Pensoft. $431 \mathrm{p}$.

Welp, T., J. Rushen, D. M. Kramer, M. Festa-Bianchet, and A. M. B. de Passille. 2004. Vigilance as a measure of fear in dairy cattle. Applied Animal Behaviour Science $87: 1-13$ 